\title{
Perceptions of obesity in a UK leisure-based population of horse owners
}

\author{
Philippa Morrison ${ }^{1 *}$, Patricia Harris ${ }^{2}$, Charlotte Maltin', Dai Grove-White ${ }^{1}$, Caroline Argo ${ }^{3}$, Clare Barfoot ${ }^{4}$ \\ From Animal Obesity - causes, consequences and comparative aspects \\ Uppsala, Sweden. 14-16 June 2015
}

\section{Introduction}

Reduced workloads, improved husbandry and increased access to energy dense forage and concentrate feeds have contributed to the high prevalence of obesity among leisure horse populations. Obesity prevalence can also be linked to our ability to recognize and manage it accordingly. Currently, owner-perception of equine obesity is poorly understood.

\section{Objective}

To evaluate owner-perceptions of equine obesity within the leisure horse sector.

\section{Methods}

Internet-based survey was distributed through UK-based equine forums. A panel of 12 lateral-images of horses and ponies were presented.

\section{Tasks included}

Asserting their involvement in the sector; identifying overweight animals; scoring the suitability of animals for participation in different equestrian activities on the basis of body weight.

\section{Results}

Of 546 respondents, $98 \%$ were female. Amateur owners exceeded professional respondents (81\%:19\%). Key findings included; that only $11 \%$ correctly identified all overweight animals (6/12), but between 37 and 98\% correctly identified individual overweight animals. Professional status did not influence an owner's ability to identify overweight animals. On assessing the weight/condition suitability of a sport horse, a cob and a pony for different disciplines, being

\footnotetext{
* Correspondence: p.k.morrison@liverpool.ac.uk

'Department of Obesity and Endocrinology, University of Liverpool, Liverpool, UK

Full list of author information is available at the end of the article
}

overweight was considered more appropriate when animals were intended to be used for showing $(\mathrm{p}<0.01)$.

\section{Conclusions}

The study provided evidence that owner's may be less able to correctly identify overweight animals by visual appearance alone. Data support our anecdotal understanding that owners consider it appropriate that horses and ponies should carry more weight when competing in showing classes. These data will aid in targeting nutritional advice for horse owners.

\begin{abstract}
Authors' details
'Department of Obesity and Endocrinology, University of Liverpool, Liverpool, UK. 'Equine Studies Group, WALTHAM Centre for Pet Nutrition, Waltham on the Wolds, Leicestershire, UK. ${ }^{3}$ School of Veterinary Medicine, University of Surrey, Guildford, Surrey, UK. ${ }^{4}$ Mars Horsecare UK Ltd., Milton Keynes, Buckinghamshire, UK.
\end{abstract}

Published: 25 September 2015

doi:10.1186/1751-0147-57-S1-06

Cite this article as: Morrison et al:: Perceptions of obesity in a UK leisure-based population of horse owners. Acta Veterinaria Scandinavica 2015 57(Suppl 1):O6.

Submit your next manuscript to BioMed Central and take full advantage of:

- Convenient online submission

- Thorough peer review

- No space constraints or color figure charges

- Immediate publication on acceptance

- Inclusion in PubMed, CAS, Scopus and Google Scholar

- Research which is freely available for redistribution 